\title{
The New Era of Drug Therapy for Obesity: The Evidence and the Expectations
}

\author{
Ben J. Jones ${ }^{1} \cdot$ Stephen R. Bloom ${ }^{1}$
}

Published online: 19 May 2015

(C) The Author(s) 2015. This article is published with open access at Springerlink.com

\begin{abstract}
There is an urgent need for effective pharmacological therapies to help tackle the growing obesity epidemic and the healthcare crisis it poses. The past 3 years have seen approval of a number of novel antiobesity drugs. The majority of these influence hypothalamic appetite pathways via dopaminergic or serotoninergic signalling. Some are combination therapies, allowing lower doses to minimize the potential for off-target effects. An alternative approach is to mimic endogenous satiety signals using long-lasting forms of peripheral appetitesuppressing hormones. There is also considerable interest in targeting thermogenesis by brown adipose tissue to increase resting energy expenditure. Obesity pharmacotherapy has seen several false dawns, but improved understanding of the pathways regulating energy balance, and better-designed trials, give many greater confidence that recently approved agents will be both efficacious and safe. Nevertheless, a number of issues from preclinical and clinical development continue to attract debate, and additional large-scale trials are still required to address areas of uncertainty.
\end{abstract}

Stephen R. Bloom

s.bloom@imperial.ac.uk

1 Section of Investigative Medicine, Hammersmith Hospital, Imperial College London, 6th Floor Commonwealth Building, Du Cane Road, London W12 0NN, UK

\section{Key Points}

For the first time in over a decade, several new drugs have been licensed for long-term weight management.

Weight reduction can be achieved pharmacologically by reducing appetite, increasing energy expenditure or both.

Improved understanding of energy homeostasis has provided novel therapeutic targets.

\section{Introduction}

The increasing global prevalence of obesity threatens to reverse the improvements in life expectancy seen over the past several decades. Currently, 600 million adults, $13 \%$ of the global population, are obese, defined as having a body mass index (BMI) of $\geq 30 \mathrm{~kg} / \mathrm{m}^{2}$ [1]. A substantial increase in childhood obesity is a particular cause for concern, as childhood BMI often persists into adulthood [2,3]. Current projections anticipate that $20 \%$ of adults will be obese by 2030 [4].

Obesity increases the risk of cardiometabolic disease, dementia, kidney disease, cancer, respiratory disease and osteoarthritis. This presents enormous healthcare challenges for the future. Preventative measures to tackle environmental determinants of obesity on a population level are essential, but so far they have been insufficiently applied to reverse the trend. Effective treatments for individuals are therefore urgently required. Lifestyle interventions can be effective, but inadequate responses are seen in a significant proportion of patients. Despite the 
gold-standard programme used in the Look AHEAD trial, only $46 \%$ of patients achieved $5 \%$ weight loss [5]. Furthermore, weight regain is common when the intensive aspect of lifestyle programmes finishes [6]. Bariatric surgery leads to sustained weight loss and long-term health benefits [7] but carries with it a small but significant perioperative mortality rate and a risk of long-term complications, and many patients choose not to undergo an invasive procedure to help them lose weight.

There is therefore a clear incentive to develop effective pharmacological treatments to aid weight loss. In this review, we summarize the physiology of energy homeostasis to reveal pharmacological targets for weight reduction, before discussing past and current treatments, novel agents in the pipeline, the regulatory hurdles they face and their position in the overall management of obesity.

\section{Strategies for Pharmacological Weight Loss}

Environment, behaviour and genetic traits all influence body weight. The final common pathway for each of these disparate factors, however, is changes in energy intake or energy expenditure. Obesity results from energy imbalance sustained over several years, and obesity treatments can work only by reversing this. Accordingly, all anti-obesity agents have at least one of the following effects:

1. Reduce food intake or nutrient absorption.

2. Increase resting or activity-related energy expenditure.

Appetite reduction is the primary weight loss mechanism for the majority of current agents. The arcuate nucleus of the hypothalamus plays a critical role in appetite regulation (see Fig. 1). It contains two key populations of neurons, which project to other hypothalamic nuclei and distant brain regions to alter feeding behaviour-one coexpresses agouti-related peptide (AgRP) and neuropeptide Y (NPY), which increase food intake, and the other coexpresses pro-opiomelanocortin (POMC) and cocaine- and amphetamine-regulated transcript (CART), which inhibit food intake. Because of the semipermeable blood-brain barrier in this region, peripheral signals indicative of energy balance-including glucose, insulin, leptin, a number of gut-derived factors including glucagon-like peptide-1 (GLP-1), peptide YY (PYY), oxyntomodulin and ghrelincan directly interact with these neurons and influence feeding behaviour [8]. POMC neuronal activity is also modulated by dopaminergic and serotoninergic signalling from other brain regions and is therefore affected by a number of central nervous system (CNS) drugs that act on these neurotransmitters [9-11]. Of course, appetite is regulated not just by physiological energy status but also

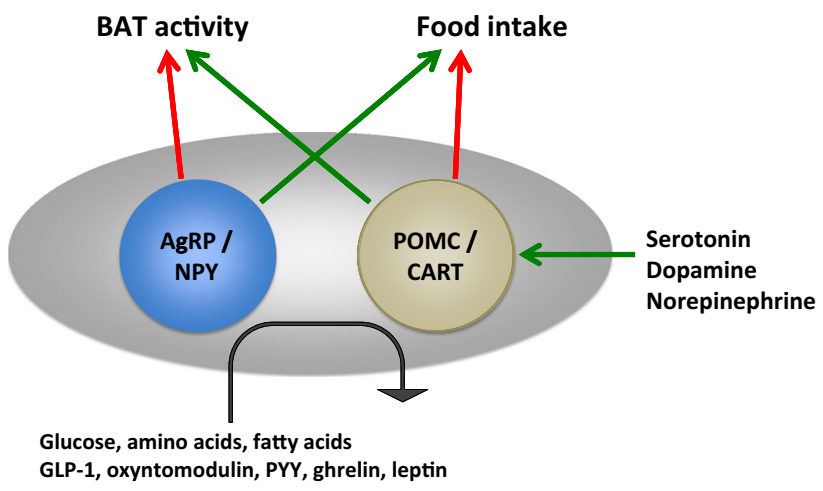

Fig. 1 Simplified schematic of hypothalamic energy regulatory pathways. Other pathways, including the reward circuitry, are involved in appetite and energy expenditure, but an understanding of the central role of the hypothalamus is useful in order to appreciate the mechanisms of action of several weight loss agents. AgRP agoutirelated peptide, $B A T$ brown adipose tissue, CART cocaine- and amphetamine-regulated transcript, GLP-1 glucagon-like peptide-1, $N P Y$ neuropeptide Y, $P O M C$ pro-opiomelanocortin, $P Y Y$ peptide $Y Y$

by environmental and emotional cues, such as the sight and smell of food. These reward-associated stimuli are integrated by the mesocorticolimbic reward system, with dopaminergic neurons originating in the ventral tegmental area (VTA) projecting to the nucleus accumbens and the prefrontal cortex, where they influence feeding behaviour [12]. Modulation of signalling in the dopaminergic reward system is also suggested as an additional mechanism for the action of some appetite suppressants [13, 14].

Interest has surged over recent years regarding the potential to increase resting energy expenditure by pharmacological activation of brown adipose tissue (BAT) [15]. Well known as a source of non-shivering thermogenesis in human infants, it was assumed not to persist into adulthood, until review of positron emission tomography (PET) images from adult cancer patients revealed extensive glucose-avid areas in the neck and thorax, subsequently identified as brown fat $[16,17]$. BAT expresses high levels of uncoupling protein-1 (UCP-1), which uncouples mitochondrial substrate utilization from ATP production, causing energy wastage [18]. The best-known activator of BAT activity is cold exposure; under thermoneutral conditions, human BAT is unlikely to play a significant role in energy homeostasis. Nevertheless, a variety of peripheral factors directly increase BAT activity, such as catecholamines, thyroid hormone, glucagon and fibroblast growth factor-21 (FGF-21) [19], raising the possibility of pharmacological manipulation. Furthermore, AgRP/NPY and POMC neurons control sympathetic innervation of BAT, revealing a central role for this system in various aspects of energy homeostasis [20-22]. This is relevant from a therapeutic point of view, as compensatory physiological and behavioural responses limit the weight 
loss that is achievable by any one mechanism [23]. Consequently, treatments that target both sides of the energy equation have the potential for greater effectiveness [24, 25]. Some studies have hinted at a possible minor role for BAT in mediating the effects of some newer anti-obesity agents [26, 27], but its current status is primarily as an area of active research with potential future therapeutic application.

\section{How Are Weight Loss Drugs Judged?}

For most obese patients, losing enough weight to return to a 'normal' BMI is unrealistic, even with bariatric surgery. Instead, the focus should be on health benefits resulting from more modest weight loss. A reduction in body weight of $5-10 \%$ is enough for significant improvements in cardiovascular risk factor profiles [28-32], kidney disease [33] and osteoarthritis [34]. Consequently, the $5 \%$ weight loss threshold features prominently in the current US Food and Drug Administration (FDA) and European Medicines Agency (EMA) guidances for approval of weight management drugs $[35,36]$. While the absolute proportions of patients achieving this degree of weight loss in clinical trials are an important metric for regulatory bodies, differences in lifestyle programmes between trials can make comparisons difficult. Therefore, $5 \%$ weight loss remains a useful target in clinical practice, but, in this review, we focus on average placebo-subtracted percentage body weight reduction as the key indicator of weight loss efficacy. Nevertheless, inferring positive health outcomes purely from weight loss is ill advised, as shown by the postapproval withdrawal of a number of agents - most recently, sibutramine due to increases in major adverse cardiac events [37]. All anti-obesity agents seeking regulatory approval now require pre-specified cardiovascular safety data as a minimum; improvements in surrogate cardiovascular risk biomarkers are also considered favourably by regulatory bodies.

\section{A Brief History of Anti-Obesity Pharmacotherapy}

In spite of a potentially lucrative market for effective pharmacological treatments for obesity, at the end of the 2000s, just one agent (orlistat) was approved for long-term use in North America and Europe. This reflected not any difficulty in producing drugs that caused weight loss, but concerns about safety, which, in many cases, were highlighted only after the drugs were brought to market. In the first half of the last century, popular 'diet pills', such as thyroxine and the respiratory chain uncoupler 2,4-dinitrophenol, were effective in producing weight loss but exposed users to thyrotoxicosis and potentially fatal hyperthermia, respectively [38]. Subsequently, amphetaminemimetic anorectic agents, such as desoxyephredine and diethylproprion, which enhance norepinephrine and dopaminergic stimulation of anorexogenic POMC neurons, enjoyed several years of popularity before the perceived addiction risk led to changes in their licences to allow short-term use only. However, in 1992, a well-publicized study demonstrated impressive results from combined use of two of these older drugs, phentermine and fenfluramine [39]. The ensuing 'phen-fen craze' came to an abrupt end in 1997, when reports emerged of valvular abnormalities in young patients taking these agents [40]. Shortly afterwards, the FDA approved sibutramine, a serotonin-noradrenaline reuptake inhibitor with an unimpressive antidepressant action but a powerful anorectic effect [41]. Use of sibutramine was terminated in Europe and the USA in 2010 after adverse cardiovascular outcomes were revealed in a post-marketing study [37]. In this study, the risk was observed only in patients with prior cardiovascular disease, and not in those at high cardiovascular risk (due to diabetes) but without prior cardiovascular disease, but the signal was sufficient for regulatory bodies to request withdrawal from the market. The well-known role of the endocannabinoid system in appetite was the target of the cannabinoid-1 (CB1) receptor antagonist rimonibant [42], licensed in Europe (but not in the USA) in 2006. The realization that some patients suffered significant psychiatric morbidity while taking this drug [43], including an increased risk of suicide, led to its rapid withdrawal from the market in 2008. In fact, the reason that FDA approval for rimonibant had been refused related to a signal of increased suicidality in the pre-marketing submission. However, the endocannabinoid system may yet prove a viable target, with non-CNS-penetrating forms of these agents believed to be less likely to lead to psychiatric morbidity [44].

\section{Anti-Obesity Agents in Current Use}

In spite of an inauspicious history, the recognition of future health crises posed by the obesity epidemic, and better understanding of the physiological mechanisms underpinning appetite and energy homeostasis, have driven significant progress in the obesity pharmacotherapy field. The past 4 years have seen approval of a number of new agents. Not all have been met with universal acclaim though; two agents (lorcaserin and phentermine/topiramate) have failed to gain approval for use in Europe. In general, both the FDA and EMA have recognized some uncertainties relating to safety and efficacy with the novel agents; however, the FDA considered the risk to benefit balance acceptable for specific issues to be addressed with post-marketing 
trials, whereas the EMA demanded that further data be obtained prior to licensing.

\subsection{Orlistat}

The only survivor from the pre-2010 era is orlistat (marketed as Xenical), an intestinally active lipase inhibitor, which reduces absorption of fat by $30 \%$ [45]. Pooled estimates from long-term studies indicate sustained weight loss of $2.9 \%$ over placebo when given at the standard dose of $120 \mathrm{mg}$ three times daily [46]. Reduced progression to diabetes [47] and improved glycaemic control in patients who already have diabetes [48] have also been noted. Fat malabsorption can give rise to side effects, including oily stools, faecal urgency and spotting if patients continue to consume a diet rich in fat, but these can be avoided with appropriate dietary restraint. Indeed, it is hypothesized that the effectiveness of orlistat likely reflects enforced dietary changes rather than a direct reduction in calorie absorption [49].

\subsection{Lorcaserin}

In 2012, lorcaserin (Belviq) was the first new anti-obesity agent to be granted an FDA licence for long-term weight management. Like fenfluramine, lorcaserin stimulates 5-HT (serotonin) receptors on anorectic POMC neurons. However, it was developed as a selective agonist of the $5-\mathrm{HT}_{2 \mathrm{C}}$ receptor to avoid $5-\mathrm{HT}_{2 \mathrm{~B}}$-mediated valvulopathies, which afflicted the earlier agent. In phase 3 trials, lorcaserin achieved average weight loss of 3.0-3.6\% better than placebo [50, 51], with 2.3 times as many patients losing at least $5 \%$ body weight in the treatment groups. Glycaemic improvements to the tune of a $0.5 \%$ reduction in glycosylated haemoglobin $\left(\mathrm{HbA}_{1 \mathrm{c}}\right)$ were seen in patients with type 2 diabetes [52]. Lorcaserin is well tolerated by most patients, with few withdrawals during phase 3 trials due to adverse events. It is currently not clear, however, whether long-term use of lorcaserin has the potential to cause valve abnormalities, despite selectivity for $5-\mathrm{HT}_{2 \mathrm{C}}$ receptors. Pooled echocardiographic data from 5249 trial participants indicated a non-statistically significant risk ratio of $1.16(95 \%$ confidence interval [CI] 0.81-1.67) for incident valvulopathy [53]. A post-marketing clinical trial of major adverse cardiac events, including valvular assessment, is intended to answer this question more conclusively. The results of this study might, however, come too late for lorcaserin to be licensed in Europe. The manufacturer withdrew its application in 2013 when it became clear that it would be unable to address the safety concerns expressed by the EMA, which pertained to the potential for psychiatric morbidity, valvulopathy and carcinogenesis.

\subsection{Phentermine/Topiramate}

Soon after lorcaserin was licensed, the FDA approved a second anti-obesity agent for long-term use: a fixed dose combination of phentermine and topiramate extended release (marketed as Qsymia). Individually, these agents were already marketed for different indications and at higher doses, as a short-term adjunct for weight loss (phentermine) and for epilepsy and migraine (topiramate). As a centrally acting appetite suppressant with a mode of action similar to that of amphetamine, phentermine's shortterm-only license reflected concerns regarding the potential for addiction [54]. Weight-lowering properties of topiramate had been noted in its initial trials as an antiseizure agent [55], but dose-limiting neuropsychiatric effects precluded its further development as an obesity monotherapy. The mechanism for topiramate-induced weight loss may involve both inhibition of orexigenic glutamate signalling [56] and increased energy utilization [57]. Combining different weight loss agents with different mechanisms of action is appealing for two reasons: first, it is less likely to be hindered by redundancy and compensation in appetite regulatory pathways; and second, it enables each component to be given at lower dose to reduce side effects. Weight loss data for phentermine/topiramate are impressive, with a placebo-subtracted body weight reduction of $6.6 \%$ at the approved dose of $7.5 \mathrm{mg}$ phentermine/46 mg topiramate [58]. Modest reductions in systolic and diastolic blood pressure of 2.3 and $0.7 \mathrm{mmHg}$, respectively, were also observed. A higher dose of $15 \mathrm{mg}$ phentermine/92 mg topiramate showed enhanced weight lowering of $9.3 \%$ better than placebo [59], but it is only recommended in selected patients who lose insufficient weight on the standard dose, because of increased adverse effects, including paraesthesia, dizziness, altered taste sensation, insomnia, constipation and xerostomia. In clinical practice, titration from an initial dose of $3.75 \mathrm{mg}$ phentermine/23 mg topiramate is employed to limit side effects. However, safety concerns, particularly with regard to teratogenicity, neuropsychiatric morbidity and cardiovascular effects, have not been addressed to the satisfaction of the EMA, which has refused to grant a license for use of Qsymia in Europe. Some of the safety worries reflected previous experience with higher doses of the individual components of Qsymia rather than direct evidence of harm from trial data, although some signals were present at the 15/92 dose, including elevated heart rate and depression. On the same evidence, the FDA took the view that careful prescribing measures and ongoing patient monitoring were adequate to sway the risk to benefit balance in favour of Qsymia. These include, in particular, a risk evaluation mitigation strategy (REMS) for the teratogenic potential of topiramate, 
requiring adequate contraception and regular pregnancy testing for ongoing use.

\subsection{Bupropion/Naltrexone}

A second combination therapy, consisting of bupropion and naltrexone (marketed as Contrave in the USA; approved name Mysimba in Europe), gained FDA and EMA approval in 2014 and 2015, respectively. Again, these agents were repurposed from existing indications. Bupropion, an aminoketone which acts as a mixed dopamine/ norepinephrine reuptake inhibitor [60], is used as an antidepressant and in smoking cession, and has previously been evaluated as monotherapy in the treatment of obesity [61]. Naltrexone is an opioid receptor antagonist, which is used to treat alcohol dependence, reducing cravings by inhibiting the action of $\beta$-endorphins on dopaminergic reward pathways [62]. Combining these two agents leads to enhanced appetite reduction, as bupropion stimulates POMC neurons and naltrexone counteracts the autoinhibitory effects of endogenous opioids they secrete [63]. Data from phase 3 trials have indicated 3.2-5.2 \% greater weight loss at 1 year over placebo [64-67], with an associated $0.5 \% \mathrm{HbA}_{1 \mathrm{c}}$ advantage in patients with type 2 diabetes. Interestingly, despite superior weight loss in the treatment groups, blood pressure reductions were actually better in the placebo groups, suggesting a treatment-related blood pressure increase. Indeed, concerns regarding cardiovascular safety were the primary reason why approval was not granted following the initial application in 2010. However, interim analysis of a subsequent cardiovascular outcomes trial provided reassurance for the regulatory bodies. Hypertension should nonetheless be controlled before treatment is initiated, and blood pressure should be carefully monitored thereafter, particularly in the first 3 months, when an adverse response is most likely to occur. When bupropion is used as monotherapy for depression or smoking cessation, it carries a black box warning stating the potential for increased suicidality. While there was no signal of psychiatric adverse events in the bupropion/naltrexone trials, the same boxed warning is included, and patients should be carefully monitored to ensure these do not develop.

\subsection{Liraglutide}

Liraglutide is the first of the GLP-1 mimetics to be granted an obesity indication (as Saxenda). GLP-1 is an endogenous incretin, released by intestinal $\mathrm{L}$ cells in response to nutrient ingestion, which enhances glucose-stimulated insulin release by pancreatic $\beta$ cells and acts on satiety pathways, including hypothalamic POMC neurons, to reduce food intake [68]. A possible role for GLP-1 in stimulating energy utilization via BAT [27] requires further investigation. Several analogues of GLP-1 are already marketed for type 2 diabetes, where their anorectic effect is well established [69]. A higher dose of liraglutide ( $3 \mathrm{mg}$, versus $1.8 \mathrm{mg}$ for type 2 diabetes) led to treatment-related weight loss of $6 \%$ over placebo [70]. Additional as-yet unpublished phase 3 data submitted by the manufacturer indicated 4.0-5.4\% weight loss over and above placebo at 1 year with liraglutide $3 \mathrm{mg}$ [71]. As expected from its pharmacology, significant improvements in glycaemic control for patients with type 2 diabetes were noted $(0.9 \%$ reduction in $\left.\mathrm{HbA}_{1 \mathrm{c}}\right)$, associated with improvements in measures of both $\beta$ cell function and insulin resistance. Like other GLP-1 agents [72, 73], liraglutide increases heart rate, an observation that has not been satisfactorily explained, but evidence suggests it is not associated with an increase in arrhythmias or hypertension. The question of whether GLP-1-based agents can increase the risk of pancreatitis has attracted considerable debate [74-77]. The increased rate of pancreatitis in diabetes and obesity [78], as well as the inherent risk of over-reporting in pharmacoepidemiological studies, makes it difficult to unequivocally identify a treatment-related adverse effect. In 2014, the FDA and EMA concluded that assertions of a causal link between incretin use and pancreatic pathology were inconsistent with current data [79]. Nevertheless, an imbalance in the incidence of pancreatitis (but not pancreatic cancer) was noted in the liraglutide weight management trials; the small numbers ( 2.4 versus 0.6 per 1000 patient years) make it difficult to draw conclusions about causality, but larger trials must be performed to address this important question. Furthermore, Saxenda, like other GLP-1 receptor agonists, carries a boxed warning regarding a possible risk of medullary thyroid cancer. This stems from preclinical studies in which an excess of medullary thyroid cancer and $\mathrm{C}$ cell hyperplasia was noted in rodents [80]; to date, there has been no evidence suggesting this is also a human phenomenon.

\section{Likely Future Developments}

The recognition of persistence of thermogenic BAT into adulthood has led to intense interest in possible ways to exploit this pharmacologically. Beyond cold exposure, sympathetic activity is the best-known activator of BAT; pheochromocytoma patients have extensive BAT deposits [81]. To be useful clinically, a sympathomimetic agent would need to be relatively specific for BAT to avoid cardiovascular sequelae. The most promising target might therefore be the $\beta 3$ adrenoreceptor, which is expressed at high levels in BAT [82], although it is also found in white adipose tissue, the gastrointestinal tract, prostate and 


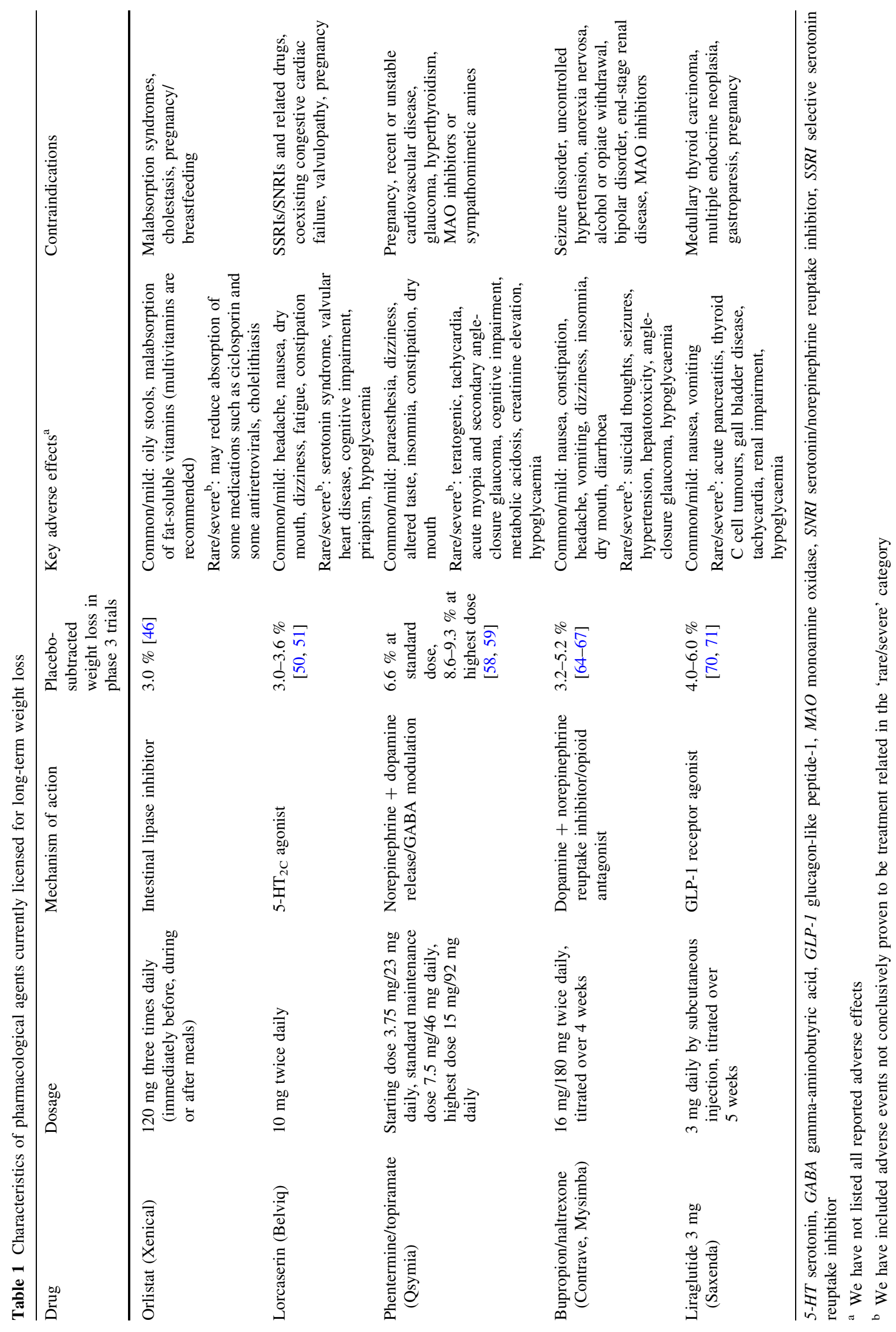


bladder [83, 84]. A $\beta 3$ agonist, mirabegron, was recently found to stimulate energy expenditure in humans [85]. In this case, however, increases in heart rate and blood pressure were noted, likely indicating action at other adrenoreceptors. The success of this approach may therefore depend on generation of agents with better selectivity for the $\beta 3$ adrenoreceptor, or alternative methods of activating BAT. A further development is the possibility that a subpopulation of white adipocytes have the potential to be 'browned', forming thermogenically active 'beige' adipose tissue and increasing the capacity for therapeutic energy wastage [86].

Another approach uses gut-derived peptides. As well as GLP-1, the endogenous counterpart of liraglutide, several other satiety hormones are released after a meal and trigger cessation of food intake. Two of particular interest are PYY and oxyntomodulin. PYY is a high-affinity agonist of the Y2 receptor, which inhibits the activity of orexigenic AgRP/NPY hypothalamic neurons [87]. Oxyntomodulin is derived from the same precursor as both glucagon and GLP-1, and is a dual agonist of both of these receptors [88, 89]. Administration of both of these peptides to humans reduces food intake [90], and, in addition to this, oxyntomodulin is able to stimulate energy expenditure, although the receptor responsible for this effect is a matter of debate [24, 91, 92]. Like GLP-1, both of these endogenous peptides last for only minutes in the circulation because of rapid enzymatic degradation, and their potential clinical use as weight loss agents relies on the development of long-lasting analogues. As enhancement of gut hormone release is suggested as a possible mechanism for the large weight reductions seen with Roux-en-Y gastric bypass, combined use of two or more of these gut-derived peptides has been suggested as a way to mimic the effect of bariatric surgery without the need for a surgical procedure [49, 93].

\section{The Position of Pharmacotherapy in the Management of Obesity}

Lifestyle measures are an essential part of any treatment plan for obesity and provide health benefits independent of weight loss. The best evidence for their effectiveness is with intensive programmes addressing diet, activity and behavioural factors $[33,94,95]$. The most powerful intervention for weight loss is bariatric surgery, which leads to an average $25-33 \%$ body weight reduction, depending on the surgical procedure. Bariatric surgery is superior to nonsurgical approaches with regard to weight loss and diabetes remission, at least in the short-to-medium term [96]. However, patients are at risk of the usual surgical complications, including perioperative death, anastomotic leak and infection, as well as longer-term issues reflecting altered gastrointestinal physiology, such as dumping syndrome, hypoglycaemia, micronutrient malabsorption and cholelithiasis [97-99]. Resource implications and risks of complications mean that surgery is generally restricted to patients with a BMI $\geq 40 \mathrm{~kg} / \mathrm{m}^{2}$, or $\geq 35 \mathrm{~kg} / \mathrm{m}^{2}$ in those with an obesity-associated comorbidity $[100,101]$.

For individuals who do not wish to undergo (or do not meet the criteria for) bariatric surgery but are unable to lose sufficient weight by lifestyle alone, pharmacotherapy is a useful adjunct. Weight loss agents are generally licensed for use in patients with a BMI $\geq 30 \mathrm{~kg} / \mathrm{m}^{2}$, or $\geq 27-28 \mathrm{~kg} /$ $\mathrm{m}^{2}$ in those with an obesity-associated comorbidity [102]. The choice of agent should reflect patient preference, relative co-indications (such as diabetes for liraglutide) and contraindications (such as seizure disorders for bupropion/ naltrexone), and relative efficacy (see Table 1). Weight loss should be assessed at 3 months, and the treatment should be discontinued or substituted if at least $5 \%$ weight loss has not been achieved.

In addition to surgery and pharmacotherapy, non-surgical interventional procedures for obesity are an exciting new development, which may widen options for weight loss management in the future. For example, the EndoBarrier system is an endoscopically inserted sleeve, which replicates some aspects of Roux-en-Y gastric bypass by accelerating nutrient delivery to the distal small intestine [103]. Implantable vagal nerve blockade devices are designed to exploit vagally mediated satiety signals to reduce food intake [104] and have been recently approved by the FDA. While these less invasive approaches are more easily reversible and less likely to cause long-term complications than bariatric surgery, they can be performed only in specialist centres; consequently, the continued role of pharmacotherapy in weight management is assured.

\section{Conclusion}

The past few years have witnessed the introduction of novel anti-obesity therapies for the first time in over a decade. Some represent refinements of older agents, some are rationally devised combinations, and some are entirely new approaches. Advancing understanding of energy homeostatic mechanisms has been essential to signposting development and continues to provide novel pharmacological targets yet to be exploited. However, our knowledge of the off-target effects of some of these agents remains incomplete, with outstanding safety concerns leading to disagreement between the major regulatory bodies regarding whether to grant approval. Research should focus on understanding the potential for adverse effects, not just the primary therapeutic aim. It remains to be seen whether medical therapy can achieve the robust 
weight loss of bariatric surgery. Currently, approved weight loss medications are not licensed for use in combination (apart from the fact that some are already polytherapies). Given the multiplicity of pathways regulating food intake and energy expenditure, however, it may be that combination therapy with more than one agent, possibly at lower doses than those licensed at present, will be a viable treatment strategy to safely maximize weight loss in the future.

Acknowledgments The Section of Investigative Medicine, Imperial College London, is funded by grants from the Medical Research Council (MRC), Biotechnology and Biological Sciences Research Council (BBSRC) and National Institute for Health Research (NIHR); an Integrative Mammalian Biology (IMB) Capacity Building Award; and an FP7-HEALTH-2009-241592 EuroCHIP grant. It is also supported by the NIHR Imperial Biomedical Research Centre Funding Scheme. Ben Jones is funded by an MRC Clinical Research Training Fellowship.

Conflict of interest The authors declare no conflicts of interest.

Open Access This article is distributed under the terms of the Creative Commons Attribution-NonCommercial 4.0 International License (http://creativecommons.org/licenses/by-nc/4.0/), which permits any noncommercial use, distribution, and reproduction in any medium, provided you give appropriate credit to the original author(s) and the source, provide a link to the Creative Commons license, and indicate if changes were made.

\section{References}

1. World Health Organization. Global status report on noncommunicable diseases 2014 [Internet]. apps.who.int. [cited 2015 Mar 1]. Available from: http://apps.who.int/iris/bitstream/ 10665/148114/1/9789241564854_eng.pdf?ua=1.

2. Vanhala M, Vanhala P, Kumpusalo E, Halonen P, Takala J. Relation between obesity from childhood to adulthood and the metabolic syndrome: population based study. BMJ. 1998; 317(7154):319.

3. Whitaker RC, Wright JA, Pepe MS, Seidel KD, Dietz WH. Predicting obesity in young adulthood from childhood and parental obesity. N Engl J Med. 1997;337(13):869-73.

4. Kelly T, Yang W, Chen C-S, Reynolds K, He J. Global burden of obesity in 2005 and projections to 2030. Int J Obes (Lond). 2008;32(9):1431-7.

5. Wadden TA, Neiberg RH, Wing RR, Clark JM, Delahanty LM, Hill JO, et al. Four-year weight losses in the Look AHEAD study: factors associated with long-term success. Obesity (Silver Spring). 2011;19(10):1987-98.

6. Price DW, Ma Y, Rubin RR, Perreault L, Bray GA, Marrero D, et al. Depression as a predictor of weight regain among successful weight losers in the Diabetes Prevention Program. Diabetes Care. 2013;36(2):216-21.

7. Sjöström L, Peltonen M, Jacobson P, Sjöström CD, Karason K, Wedel $\mathrm{H}$, et al. Bariatric surgery and long-term cardiovascular events. JAMA. 2012;307(1):56-65.

8. Suzuki K, Simpson KA, Minnion JS, Shillito JC, Bloom SR. The role of gut hormones and the hypothalamus in appetite regulation. Endocr J. 2010;57(5):359-72.
9. Domecq JP, Prutsky G, Leppin A, Sonbol MB, Altayar O, Undavalli $\mathrm{C}$, et al. Drugs commonly associated with weight change: a systematic review and meta-analysis. J Clin Endocrinol Metab. 2015;100(2):363-70.

10. Roepke TA, Smith AW, Rønnekleiv OK, Kelly MJ. Serotonin $5-\mathrm{HT}_{2 \mathrm{C}}$ receptor-mediated inhibition of the M-current in hypothalamic POMC neurons. Am J Physiol Endocrinol Metab. 2012;302(11):E1399-406.

11. Chu S-C, Chen P-N, Hsieh Y-S, Yu C-H, Lin M-H, Lin Y-H, et al. Involvement of hypothalamic PI3K-STAT3 signalling in regulating appetite suppression mediated by amphetamine. Br J Pharmacol. 2014;171(13):3223-33.

12. MacDonald AF, Billington CJ, Levine AS. Alterations in food intake by opioid and dopamine signaling pathways between the ventral tegmental area and the shell of the nucleus accumbens. Brain Res. 2004;1018(1):78-85.

13. Kim E-M, Quinn JG, Spanswick D, O’Hare E. Feeding association between the nucleus of the solitary tract and the ventral tegmental area. Appetite. 2009;53(3):457-60.

14. Mietlicki-Baase EG, Ortinski PI, Rupprecht LE, Olivos DR, Alhadeff AL, Pierce RC, et al. The food intake-suppressive effects of glucagon-like peptide-1 receptor signaling in the ventral tegmental area are mediated by AMPA/kainate receptors. Am J Physiol Endocrinol Metab. 2013;305(11):E1367-74.

15. Poher A-L, Altirriba J, Veyrat-Durebex C, Rohner-Jeanrenaud F. Brown adipose tissue activity as a target for the treatment of obesity/insulin resistance. Front Physiol. 2015;6:4.

16. Virtanen KA, Lidell ME, Orava J, Heglind M, Westergren R, Niemi $\mathrm{T}$, et al. Functional brown adipose tissue in healthy adults. N Engl J Med. 2009;360(15):1518-25.

17. Cypess AM, Lehman S, Williams G, Tal I, Rodman D, Goldfine $\mathrm{AB}$, et al. Identification and importance of brown adipose tissue in adult humans. N Engl J Med. 2009;360(15):1509-17.

18. Busiello RA, Savarese S, Lombardi A. Mitochondrial uncoupling proteins and energy metabolism. Front Physiol. 2015;6:36.

19. Schulz TJ, Tseng Y-H. Systemic control of brown fat thermogenesis: integration of peripheral and central signals. Ann N Y Acad Sci. 2013;1302:35-41.

20. Billington CJ, Briggs JE, Grace M, Levine AS. Effects of intracerebroventricular injection of neuropeptide $\mathrm{Y}$ on energy metabolism. Am J Physiol. 1991;260(2 Pt 2):R321-7.

21. Shi Y-C, Lau J, Lin Z, Zhang H, Zhai L, Sperk G, et al. Arcuate NPY controls sympathetic output and BAT function via a relay of tyrosine hydroxylase neurons in the PVN. Cell Metab. 2013;17(2):236-48.

22. Morgan DA, McDaniel LN, Yin T, Khan M, Jiang J, Acevedo $\mathrm{MR}$, et al. Regulation of glucose tolerance and sympathetic activity by MC4R signaling in the lateral hypothalamus. Diabetes. 2015. doi:10.2337/db14-1257.

23. Dhurandhar EJ, Kaiser KA, Dawson JA, Alcorn AS, Keating $\mathrm{KD}$, Allison DB. Predicting adult weight change in the real world: a systematic review and meta-analysis accounting for compensatory changes in energy intake or expenditure. Int $\mathbf{J}$ Obes (Lond). 2014. doi:10.1038/ijo.2014.184.

24. Pocai A. Action and therapeutic potential of oxyntomodulin. Mol Metab. 2014;3(3):241-51.

25. Troke RC, Tan TM, Bloom SR. The future role of gut hormones in the treatment of obesity. Ther Adv Chronic Dis. 2014;5(1):4-14.

26. Caricilli AM, Penteado E, de Abreu LL, Quaresma PGF, Santos AC, Guadagnini D, et al. Topiramate treatment improves hypothalamic insulin and leptin signaling and action and reduces obesity in mice. Endocrinology. 2012;153(9):4401-11.

27. Beiroa D, Imbernon M, Gallego R, Senra A, Herranz D, Villarroya F, et al. GLP-1 agonism stimulates brown adipose tissue 
thermogenesis and browning through hypothalamic AMPK. Diabetes. 2014;63(10):3346-58.

28. Goldstein DJ. Beneficial health effects of modest weight loss. Int J Obes Relat Metab Disord. 1992;16(6):397-415.

29. Blackburn G. Effect of degree of weight loss on health benefits. Obes Res. 1995;3(Suppl 2):211s-6s.

30. Vidal J. Updated review on the benefits of weight loss. Int $\mathbf{J}$ Obes Relat Metab Disord. 2002;26(Suppl 4):S25-8.

31. Wing RR, Lang W, Wadden TA, Safford M, Knowler WC, Bertoni AG, et al. Benefits of modest weight loss in improving cardiovascular risk factors in overweight and obese individuals with type 2 diabetes. Diabetes Care. 2011;34(7):1481-6.

32. Knowler WC, Barrett-Connor E, Fowler SE, Hamman RF, Lachin JM, Walker EA, et al. Reduction in the incidence of type 2 diabetes with lifestyle intervention or metformin. N Engl $\mathbf{J}$ Med. 2002;346(6):393-403.

33. Look AHEAD Research Group. Effect of a long-term behavioural weight loss intervention on nephropathy in overweight or obese adults with type 2 diabetes: a secondary analysis of the Look AHEAD randomised clinical trial. Lancet Diabetes Endocrinol. 2014;2(10):801-9.

34. Christensen R, Bartels EM, Astrup A, Bliddal H. Effect of weight reduction in obese patients diagnosed with knee osteoarthritis: a systematic review and meta-analysis. Ann Rheum Dis. 2007;66(4):433-9.

35. Colman E. Food and Drug Administration's obesity drug guidance document: a short history. Circulation. 2012;125(17): 2156-64.

36. European Medicines Agency. Guidelines on clinical evaluation of medicinal products used in weight control [Internet]. ema.europa.eu. [cited 2015 Mar 1]. Available from: http://www.ema. europa.eu/docs/en_GB/document_library/Scientific_guideline/ 2009/09/WC500003264.pdf.

37. James WPT, Caterson ID, Coutinho W, Finer N, Van Gaal LF, Maggioni AP, et al. Effect of sibutramine on cardiovascular outcomes in overweight and obese subjects. N Engl J Med. 2010;363(10):905-17.

38. Colman E. Dinitrophenol and obesity: an early twentieth-century regulatory dilemma. Regul Toxicol Pharmacol. 2007;48(2): $115-7$.

39. Weintraub M, Sundaresan PR, Madan M, Schuster B, Balder A, Lasagna L, et al. Long-term weight control study. I (weeks 0 to 34). The enhancement of behavior modification, caloric restriction, and exercise by fenfluramine plus phentermine versus placebo. Clin Pharmacol Ther. 1992;51(5):586-94.

40. Connolly HM, Crary JL, McGoon MD, Hensrud DD, Edwards BS, Edwards WD, et al. Valvular heart disease associated with fenfluramine-phentermine. N Engl J Med. 1997;337(9):581-8.

41. Rolls BJ, Shide DJ, Thorwart ML, Ulbrecht JS. Sibutramine reduces food intake in non-dieting women with obesity. Obes Res. 1998;6(1):1-11.

42. Pi-Sunyer FX, Aronne LJ, Heshmati HM, Devin J, Rosenstock J, RIO-North America Study Group. Effect of rimonabant, a cannabinoid-1 receptor blocker, on weight and cardiometabolic risk factors in overweight or obese patients: RIO-North America: a randomized controlled trial. JAMA. 2006;295(7):761-75.

43. Topol EJ, Bousser M-G, Fox KAA, Creager MA, Despres J-P, Easton JD, et al. Rimonabant for prevention of cardiovascular events (CRESCENDO): a randomised, multicentre, placebocontrolled trial. Lancet. 2010;376(9740):517-23.

44. Chorvat RJ, Berbaum J, Seriacki K, McElroy JF. JD-5006 and JD-5037: peripherally restricted (PR) cannabinoid-1 receptor blockers related to SLV-319 (Ibipinabant) as metabolic disorder therapeutics devoid of CNS liabilities. Bioorg Med Chem Lett. 2012;22(19):6173-80.
45. Hauptman JB, Jeunet FS, Hartmann D. Initial studies in humans with the novel gastrointestinal lipase inhibitor Ro 18-0647 (tetrahydrolipstatin). Am J Clin Nutr. 1992;55(1 Suppl):309S-13S.

46. Rucker D, Padwal R, Li SK, Curioni C, Lau DCW. Long term pharmacotherapy for obesity and overweight: updated metaanalysis. BMJ. 2007;335(7631):1194-9.

47. Torgerson JS, Hauptman J, Boldrin MN, Sjöström L. Xenical in the Prevention of Diabetes in Obese Subjects (XENDOS) study: a randomized study of orlistat as an adjunct to lifestyle changes for the prevention of type 2 diabetes in obese patients. Diabetes Care. 2004;27(1):155-61.

48. Hanefeld M, Sachse G. The effects of orlistat on body weight and glycaemic control in overweight patients with type 2 diabetes: a randomized, placebo-controlled trial. Diabetes Obes Metab. 2002;4(6):415-23.

49. Miras AD, le Roux CW. Can medical therapy mimic the clinical efficacy or physiological effects of bariatric surgery? Int J Obes (Lond). 2014;38(3):325-33.

50. Smith SR, Weissman NJ, Anderson CM, Sanchez M, Chuang E, Stubbe S, et al. Multicenter, placebo-controlled trial of lorcaserin for weight management. N Engl J Med. 2010;363(3): 245-56.

51. Fidler MC, Sanchez M, Raether B, Weissman NJ, Smith SR, Shanahan WR, et al. A one-year randomized trial of lorcaserin for weight loss in obese and overweight adults: the BLOSSOM trial. J Clin Endocrinol Metab. 2011;96(10):3067-77.

52. O'Neil PM, Smith SR, Weissman NJ, Fidler MC, Sanchez M, Zhang J, et al. Randomized placebo-controlled clinical trial of lorcaserin for weight loss in type 2 diabetes mellitus: the BLOOMDM study. Obesity (Silver Spring). 2012;20(7):1426-36.

53. Weissman NJ, Sanchez M, Koch GG, Smith SR, Shanahan WR, Anderson CM. Echocardiographic assessment of cardiac valvular regurgitation with lorcaserin from analysis of 3 phase 3 clinical trials. Circ Cardiovasc Imaging. 2013;6(4):560-7.

54. Colman E. Anorectics on trial: a half century of federal regulation of prescription appetite suppressants. Ann Intern Med. 2005;143(5):380-5.

55. Ben-Menachem E, Henriksen O, Dam M, Mikkelsen M, Schmidt D, Reid S, et al. Double-blind, placebo-controlled trial of topiramate as add-on therapy in patients with refractory partial seizures. Epilepsia. 1996;37(6):539-43.

56. Kaminski RM, Banerjee M, Rogawski MA. Topiramate selectively protects against seizures induced by ATPA, a GluR5 kainate receptor agonist. Neuropharmacology. 2004;46(8): 1097-104.

57. Picard F, Deshaies Y, Lalonde J, Samson P, Richard D. Topiramate reduces energy and fat gains in lean $(\mathrm{Fa} /$ ?) and obese (fa/fa) Zucker rats. Obes Res. 2000;8(9):656-63.

58. Gadde KM, Allison DB, Ryan DH, Peterson CA, Troupin B, Schwiers ML, et al. Effects of low-dose, controlled-release, phentermine plus topiramate combination on weight and associated comorbidities in overweight and obese adults $(\mathrm{CON}$ QUER): a randomised, placebo-controlled, phase 3 trial. Lancet. 2011;377(9774):1341-52.

59. Allison DB, Gadde KM, Garvey WT, Peterson CA, Schwiers ML, Najarian T, et al. Controlled-release phentermine/topiramate in severely obese adults: a randomized controlled trial (EQUIP). Obesity (Silver Spring). 2012;20(2):330-42.

60. Stahl SM, Pradko JF, Haight BR, Modell JG, Rockett CB, Learned-Coughlin S. A review of the neuropharmacology of bupropion, a dual norepinephrine and dopamine reuptake inhibitor. Prim Care Companion J Clin Psychiatry. 2004;6(4): 159-66.

61. Anderson JW, Greenway FL, Fujioka K, Gadde KM, McKenney J, O'Neil PM. Bupropion SR enhances weight loss: a 48-week 
double-blind, placebo- controlled trial. Obes Res. 2002;10(7): 633-41.

62. Johnson BA. Update on neuropharmacological treatments for alcoholism: scientific basis and clinical findings. Biochem Pharmacol. 2008;75(1):34-56.

63. Greenway FL, Whitehouse MJ, Guttadauria M, Anderson JW, Atkinson RL, Fujioka K, et al. Rational design of a combination medication for the treatment of obesity. Obesity (Silver Spring). 2009;17(1):30-9.

64. Wadden TA, Foreyt JP, Foster GD, Hill JO, Klein S, O’Neil PM, et al. Weight loss with naltrexone SR/bupropion SR combination therapy as an adjunct to behavior modification: the CORBMOD trial. Obesity (Silver Spring). 2011;19(1):110-20.

65. Hollander P, Gupta AK, Plodkowski R, Greenway F, Bays H, Burns C, et al. Effects of naltrexone sustained-release/bupropion sustained-release combination therapy on body weight and glycemic parameters in overweight and obese patients with type 2 diabetes. Diabetes Care. 2013;36(12):4022-9.

66. Apovian CM, Aronne L, Rubino D, Still C, Wyatt H, Burns C, et al. A randomized, phase 3 trial of naltrexone SR/bupropion SR on weight and obesity-related risk factors (COR-II). Obesity (Silver Spring). 2013;21(5):935-43.

67. Greenway FL, Fujioka K, Plodkowski RA, Mudaliar S, Guttadauria M, Erickson J, et al. Effect of naltrexone plus bupropion on weight loss in overweight and obese adults (COR-I): a multicentre, randomised, double-blind, placebo-controlled, phase 3 trial. Lancet. 2010;376(9741):595-605.

68. Murphy KG, Bloom SR. Gut hormones and the regulation of energy homeostasis. Nature. 2006;444(7121):854-9.

69. Nauck M, Frid A, Hermansen K, Shah NS, Tankova T, Mitha $\mathrm{IH}$, et al. Efficacy and safety comparison of liraglutide, glimepiride, and placebo, all in combination with metformin, in type 2 diabetes: the LEAD (Liraglutide Effect and Action in Diabetes)-2 study. Diabetes Care. 2009;32(1):84-90.

70. Wadden TA, Hollander P, Klein S, Niswender K, Woo V, Hale $\mathrm{PM}$, et al. Weight maintenance and additional weight loss with liraglutide after low-calorie-diet-induced weight loss: the SCALE Maintenance randomized study. Int $\mathrm{J}$ Obes (Lond). 2013;37(11):1443-51.

71. FDA briefing information: meeting of the Endocrinologic and Metabolic Drugs Advisory Committee, May 11, 2014. [Internet]. fda.gov. [cited 2015 Mar 3]. Available from: http://www.fda. gov/downloads/advisorycommittees/committeesmeetingmaterials/ drugs/endocrinologicandmetabolicdrugsadvisorycommittee/ucm 413318.pdf.

72. Mundil D, Cameron-Vendrig A, Husain M. GLP-1 receptor agonists: a clinical perspective on cardiovascular effects. Diab Vasc Dis Res. 2012;9(2):95-108.

73. Ferdinand KC, White WB, Calhoun DA, Lonn EM, Sager PT, Brunelle R, et al. Effects of the once-weekly glucagon-like peptide-1 receptor agonist dulaglutide on ambulatory blood pressure and heart rate in patients with type 2 diabetes mellitus. Hypertension. 2014;64(4):731-7.

74. Parks M, Rosebraugh C. Weighing risks and benefits of liraglutide-the FDA's review of a new antidiabetic therapy. N Engl J Med. 2010;362(9):774-7.

75. Butler PC, Matveyenko AV, Dry S, Bhushan A, Elashoff R. Glucagon-like peptide-1 therapy and the exocrine pancreas: innocent bystander or friendly fire? Diabetologia. 2010;53(1):1-6.

76. Olansky L. Do incretin-based therapies cause acute pancreatitis? J Diabetes Sci Technol. 2010;4(1):228-9.

77. Chalmer T, Almdal TP, Vilsbøll T, Knop FK. Adverse drug reactions associated with the use of liraglutide in patients with type 2 diabetes-focus on pancreatitis and pancreas cancer. Expert Opin Drug Saf. 2015;14(1):171-80.
78. Noel RA, Braun DK, Patterson RE, Bloomgren GL. Increased risk of acute pancreatitis and biliary disease observed in patients with type 2 diabetes: a retrospective cohort study. Diabetes Care. 2009;32(5):834-8.

79. Egan AG, Blind E, Dunder K, de Graeff PA, Hummer BT, Bourcier T, et al. Pancreatic safety of incretin-based drugsFDA and EMA assessment. N Engl J Med. 2014;370(9):794-7.

80. Rosol TJ. On-target effects of GLP-1 receptor agonists on thyroid C-cells in rats and mice. Toxicol Pathol. 2013;41(2):303-9.

81. Lean ME, James WP, Jennings G, Trayhurn P. Brown adipose tissue in patients with phaeochromocytoma. Int $\mathrm{J}$ Obes. 1986;10(3):219-27.

82. Nahmias C, Blin N, Elalouf JM, Mattei MG, Strosberg AD, Emorine LJ. Molecular characterization of the mouse beta 3-adrenergic receptor: relationship with the atypical receptor of adipocytes. EMBO J. 1991;10(12):3721-7.

83. Berkowitz DE, Nardone NA, Smiley RM, Price DT, Kreutter DK, Fremeau RT, et al. Distribution of beta 3-adrenoceptor mRNA in human tissues. Eur J Pharmacol. 1995;289(2):223-8.

84. Fujimura T, Tamura K, Tsutsumi T, Yamamoto T, Nakamura K, Koibuchi Y, et al. Expression and possible functional role of the beta3-adrenoceptor in human and rat detrusor muscle. J Urol. 1999;161(2):680-5.

85. Cypess AM, Weiner LS, Roberts-Toler C, Elía EF, Kessler SH, Kahn PA, et al. Activation of human brown adipose tissue by a $\beta 3$-adrenergic receptor agonist. Cell Metab. 2015;21(1):33-8.

86. Diaz MB, Herzig S, Vegiopoulos A. Thermogenic adipocytes: from cells to physiology and medicine. Metab Clin Exp. 2014;63(10):1238-49.

87. Batterham RL, Cowley MA, Small CJ, Herzog H, Cohen MA, Dakin CL, et al. Gut hormone PYY(3-36) physiologically inhibits food intake. Nature. 2002;418(6898):650-4.

88. Dakin CL, Gunn I, Small CJ, Edwards CM, Hay DL, Smith DM, et al. Oxyntomodulin inhibits food intake in the rat. Endocrinology. 2001;142(10):4244-50.

89. Pocai A. Unraveling oxyntomodulin, GLP1's enigmatic brother. J Endocrinol. 2012;215(3):335-46.

90. Field BCT, Wren AM, Peters V, Baynes KCR, Martin NM, Patterson M, et al. PYY3-36 and oxyntomodulin can be additive in their effect on food intake in overweight and obese humans. Diabetes. 2010;59(7):1635-9.

91. Lockie SH, Heppner KM, Chaudhary N, Chabenne JR, Morgan DA, Veyrat-Durebex C, et al. Direct control of brown adipose tissue thermogenesis by central nervous system glucagonlike peptide-1 receptor signaling. Diabetes. 2012;61(11): 2753-62.

92. Kosinski JR, Hubert J, Carrington PE, Chicchi GG, Mu J, Miller $\mathrm{C}$, et al. The glucagon receptor is involved in mediating the body weight-lowering effects of oxyntomodulin. Obesity (Silver Spring). 2012;20(8):1566-71.

93. Finan B, Yang B, Ottaway N, Smiley DL, Ma T, Clemmensen $\mathrm{C}$, et al. A rationally designed monomeric peptide triagonist corrects obesity and diabetes in rodents. Nat Med. 2015;21(1):27-36.

94. Wadden TA, Volger S, Sarwer DB, Vetter ML, Tsai AG, Berkowitz RI, et al. A two-year randomized trial of obesity treatment in primary care practice. N Engl J Med. 2011;365(21): 1969-79.

95. Kushner RF, Ryan DH. Assessment and lifestyle management of patients with obesity: clinical recommendations from systematic reviews. JAMA. 2014;312(9):943-52.

96. Gloy VL, Briel M, Bhatt DL, Kashyap SR, Schauer PR, Mingrone $\mathrm{G}$, et al. Bariatric surgery versus non-surgical treatment for obesity: a systematic review and meta-analysis of randomised controlled trials. BMJ. 2013;347:f5934. 
97. Puzziferri N, Roshek TB, Mayo HG, Gallagher R, Belle SH, Livingston EH. Long-term follow-up after bariatric surgery: a systematic review. JAMA. 2014;312(9):934-42.

98. Tack J, Deloose E. Complications of bariatric surgery: dumping syndrome, reflux and vitamin deficiencies. Best Pract Res Clin Gastroenterol. 2014;28(4):741-9.

99. Bonfrate L, Wang DQ-H, Garruti G, Portincasa P. Obesity and the risk and prognosis of gallstone disease and pancreatitis. Best Pract Res Clin Gastroenterol. 2014;28(4):623-35.

100. Jensen MD, Ryan DH, Apovian CM, Ard JD, Comuzzie AG, Donato KA, et al. 2013 AHA/ACC/TOS guideline for the management of overweight and obesity in adults: a report of the American College of Cardiology/American Heart Association Task Force on Practice Guidelines and the Obesity Society. J Am Coll Cardiol. 2014;63(25 Pt B):2985-3023.

101. National Institute for Health and Care Excellence. Obesity: identification, assessment and management of overweight and obesity in children, young people and adults [Internet]. nice. org.uk. [cited 2015 Mar 8]. Available from: https://www.nice.org. uk/guidance/cg189/resources/guidance-obesity-identificationassessment-and-management-of-overweight-and-obesity-inchildren-young-people-and-adults-pdf.

102. Apovian CM, Aronne LJ, Bessesen DH, McDonnell ME, Murad MH, Pagotto U, et al. Pharmacological management of obesity: an Endocrine Society clinical practice guideline. J Clin Endocrinol Metab. 2015;100(2):342-62.

103. Rohde U, Hedbäck N, Gluud LL, Vilsbøll T, Knop FK. Effect of the EndoBarrier gastrointestinal liner on obesity and type 2 diabetes: protocol for systematic review and meta-analysis of clinical studies. BMJ Open. 2013;3(9):e003417.

104. Ikramuddin S, Blackstone RP, Brancatisano A, Toouli J, Shah SN, Wolfe BM, et al. Effect of reversible intermittent intra-abdominal vagal nerve blockade on morbid obesity: the ReCharge randomized clinical trial. JAMA. 2014;312(9):915-22. 